WARSZTATY Z GEOGRAFII TURYZMU

ISBN 978-83-7525-925-4 $\quad$ s. 137-157

http://dx.doi.org/10.18778/7525-925-4.11

Jolanta LATOSIŃSKA

Armina MUSZYŃSKA

Uniwersytet Łódzki

\title{
STARE I NOWE FORMY TURYSTYKI W PRZESTRZENI - SPALSKI JARMARK ANTYKÓW I RĘKODZIEŁA LUDOWEGO W ŚWIETLE BADAŃ RUCHU TURYSTYCZNEGO
}

\section{Wstęp}

Celem opracowania jest ukazanie starego zjawiska w nowej, turystycznej odsłonie $\mathrm{w}$ świetle badań ruchu turystycznego. Jarmarki, znane od średniowiecza jako miejsce wymiany i handlu, były ówcześnie gospodarczą koniecznością. Odbywały się corocznie $\mathrm{w}$ stałych terminach. Na przełomie XVII i XVIII w. wraz z rozwojem handlu i komunikacji rola jarmarków uległa ograniczeniu. Przez cały czas swego istnienia jarmarki pełniły istotną funkcję w procesie tworzenia charakterystycznej kultury jako miejsca wymiany nie tylko towarów, ale również obyczajów i informacji, jako miejsca spotkań (Wielka encyklopedia... 2002). W czasach nam współczesnych, choć nadal obecne $w$ tradycyjnej formie, jarmarki odrodziły się również jako turystyczna atrakcja, a o ich istnieniu decyduje nie konieczność, lecz pomysł, wola spotkania, dokonania zakupu, wymiany lub chęć obejrzenia jako wystawy. Nie bez znaczenia pozostaje miejsce. W przypadku Spalskiego Jarmarku Antyków i Rękodzieła Ludowego jest to znana w kraju miejscowość turystyczna - 
Spała, która rokrocznie odwiedzana jest przez dziesiątki tysięcy gości. Miejscowość ta od dawna i na trwałe zapisała się na turystycznej mapie kraju, a jarmark jako jedno z ważniejszych wydarzeń trwających od wiosny do jesieni.

\section{Ruch turystyczny w Spale w świetle badań terenowych w latach 2010-2012}

Turystyka to w literaturze przedmiotu często definiowane zjawisko. W kontekście niniejszego opracowania warto zwrócić uwagę na definicję K. PRZECŁAWSKIEGO (1996), który turystykę postrzega przede wszystkim jako zachowanie człowieka. Autor pisze: „turystyka to całokształt zjawisk ruchliwości przestrzennej, związanych z dobrowolną czasową zmianą miejsca pobytu, rytmu i środowiska życia, oraz wejściem w styczność osobistą ze środowiskiem odwiedzanym (przyrodniczym, kulturowym bądź społecznym)" (PRZECŁAWSKI 1996, s. 30). Zjawisko to należy rozpatrywać w płaszczyźnie przestrzennej, ekonomicznej, socjologicznej, psychologicznej i kulturowej. Spała stanowi obszar, na którym realizowane są różnorodne formy aktywności turystycznej człowieka, to miejsce, gdzie spotykają się zróżnicowani pod względem motywu, upodobań i uwarunkowań goście: wczasowicze, miłośnicy krajoznawstwa i turystyki kwalifikowanej, sportowcy, goście korporacyjni, biznesowi, uczestnicy konferencji i seminariów, organizowane są zielone szkoły dla dzieci i młodzieży oraz spotkania oazowe. Od ponad roku w Spale funkcjonuje Terenowa Stacja Przyrodnicza Uniwersytetu Łódzkiego, która jest miejscem pracy i spotkań pracowników nauki i studentów.

Przebywający w Spale goście korzystają z szeroko pojętego zagospodarowania turystyczno-sportowo-rekreacyjnego, dlatego, niezależnie od motywu przybycia, zostali uwzględnieni w badaniach i statystykach turystycznych.

Jak wykazały badania prowadzone w Spale w latach 2010-2011 oraz analiza wybranych mierników funkcji turystycznej, Spałę należy uznać za miejscowość o dobrze rozwiniętej funkcji turystycznej (LATOSIŃSKA, ŻEK 2011). W 2009 r. liczba turystycznych miejsc noclegowych przypadających na 100 stałych mieszkańców wynosiła tam 276,55 (miernik Baretje'a-Deferta), liczba turystów korzystających z noclegów przypadających na $1 \mathrm{~km}^{2}$ powierzchni badanego obszaru (sołectwo Spała) - 5411,08 (miernik Deferta), liczba osób 
korzystających z noclegów przypadających na 100 stałych mieszkańców 14 365,71 (miernik Schneidera), a gęstość bazy noclegowej wyrażona liczbą miejsc noclegowych przypadająca na $1 \mathrm{~km}^{2}$ powierzchni - 104,17. Liczba miejsc w obiektach noclegowych Spały wynosi maksymalnie 1250. Ruch turystyczny w bazie noclegowej obliczono w 2009 r. na 64 933, co należy przyjąć jako wartość szacunkową ze względu na brak danych z dwóch obiektów spośród 12 ówcześnie funkcjonujących. Badania ankietowe w roku 2010 (249 osób) wykazały średnią długość pobytu dla 50\% gości jako 2-3 dni, a dla pozostałych 50\% jako 4-7 dni. Obłożenie bazy noclegowej kształtowało się w 2009 r. na poziomie około 45\%, przy czym w Ośrodku Przygotowań Olimpijskich (OPO) osiagnęło poziom najwyższy (65,9\%), a w pozostałych obiektach od 20\% (na plebanii) wzwyż. Ruch turystyczny jest główną determinantą rozwoju funkcji turystycznej miejscowości czy obszaru. Natomiast zasięg przestrzenny ruchu wypoczynkowego dokumentuje rangę Spały głównie jako lokalną i regionalną i tylko w niewielkim stopniu ponadregionalną. $\mathrm{W}$ ciągu ostatnich 20 lat profil klienta zmienił się $\mathrm{z}$,wczasowicza wypoczywającego z rodziną od maja do września" głównie na turystę wypoczywającego aktywnie, uczestnika konferencji, seminariów, spotkań biznesowych, integracyjnych, turystę korporacyjnego. Ponadto w Spale organizowane są wiosną i jesienią "zielone szkoły” dla dzieci i młodzieży przede wszystkim z regionu łódzkiego (LATOSIŃSKA, ŻEK 2011).

Badania przeprowadzone $\mathrm{w}$ obiektach noclegowych $\mathrm{w}$ roku 2012 korespondują z prowadzonymi w latach 2010-2011 i potwierdziły ogólne tendencje dotyczące obłożenia miejsc noclegowych ${ }^{1}$. Dane statystyczne pozyskane za 2011 r. w dziewięciu spośród 13 funkcjonujących obiektów pozwoliły określić poziom obłożenia miejsc noclegowych na 49,2\%. Aby obliczyć ten wskaźnik wzięto pod uwagę 997 miejsc noclegowych (83\%) i 178747 osobonoclegów. Najwyższe obłożenie zanotowano w OPO $(68,5 \%)$, a najniższe $(20 \%)$ na plebanii. W obiektach o najwyższym standardzie wskaźnik ten kształtował się w 2011 r. na poziomie 45\% w przypadku hotelu „Mościcki” i $36 \%$ w przypadku hotelu „Prezydent”.

Na podstawie materiału zebranego w czerwcu 2012 r. można stwierdzić, że funkcja turystyczna Spały w przypadku gości „sportowych” ma zasięg

\footnotetext{
${ }^{1}$ Materiał został zebrany podczas ćwiczeń terenowych w Spale przez pozostających pod opieką autorek studentów I roku uzupełniających studiów magisterskich "turystyka i rekreacja", studiów stacjonarnych (8-14 czerwca 2012 r., od piątku do czwartku) i studiów niestacjonarnych (18-22 czerwca 2012 r., od poniedziałku do piątku).
} 
krajowy i międzynarodowy, w przypadku turystyki biznesowej i korporacyjnej czy konferencyjnej i seminaryjnej - zasięg głównie krajowy, natomiast jeżeli chodzi o turystykę wypoczynkową i krajoznawczą oraz turystykę dzieci i młodzieży potwierdza się zbadany w 2011 r. zasięg regionalny i ponadregionalny (zarówno na podstawie badań ankietowych, jak i informacji uzyskanych w obiektach noclegowych). W zasięgu przestrzennym (według kart inwentaryzacyjnych bazy noclegowej) odnotowano wszystkie województwa, w tym najliczniej reprezentowane były: łódzkie i mazowieckie (po $13 \%$ ), następnie pomorskie i małopolskie (po $8 \%$ ), a najmniej licznie dolnośląskie i kujawsko-pomorskie (po 4\%), pozostałe wykazały udział około 5\%. Na podstawie opinii właścicieli obiektów noclegowych stwierdzono, że zasięg krajowy ma przede wszystkim turystyka biznesowa, korporacyjna i konferencyjna. Niestety szczegółowych danych na poziomie obiektów nie udostępniono.

Materiały pozyskane w 2012 r. w OPO (w dziale marketingu) dowodza, iż zasięg przestrzenny sportowców dokumentuje rangę krajową i międzynarodową. Rocznie w Ośrodku Przygotowań Olimpijskich przebywa około 20 tys. gości (ruch sportowy i pozasportowy), gdzie udzielanych jest ponad 90 tys. (91 797) osobonoclegów, z czego 78,8\% (2011 r.) przypada na ruch sportowy, a $21,2 \%$ na pozasportowy. Udział zagranicznego ruchu sportowego w obłożeniu OPO przez sportowców wynosi $15,4 \%$, a w całkowitym obłożeniu - 7,1\%. W 2011 r. sportowcy zagraniczni przybyli z 48 krajów świata, najliczniej z Wielkiej Brytanii (136 osób, w tym 108 z Walii), Rosji (102) Ukrainy (91), Czech (89), Niemiec (55), Węgier (54), Austrii (44), Algierii (40), Litwy i Brazylii (po 34), Francji (33), Słowacji (25), Zjednoczonych Emiratów Arabskich (23), Włoch i USA (po 19), Bułgarii (18), Chorwacji (11), Gruzji, Łotwy, Rumunii (po 10), Hiszpanii, Szwecji, Kanady (po 8), Estonii (7), Białorusi, Danii, Japonii (po 5), Holandii, Armenii, Arabii Saudyjskiej, Turcji (po 3), Egiptu, Meksyku, Portugalii, Belgii, Bośni i Hercegowiny, Szwajcarii, Cypru (po 2), Jamajki, Maroka, Finlandii, Kamerunu, Nigerii, Kuwejtu, Słowenii, Dominikany, Kuby i Izraela (po 1). W przypadku 58,3\% (28 krajów) były to kraje europejskie, pozostałe 20 (41,7\%) - pozaeuropejskie. Rocznie do OPO w Spale przyjeżdża około 17 tys. gości krajowych (w $2010 \mathrm{r}$. zanotowano 16852 osoby) ze wszystkich województw, co dokumentuje rangę krajową tego ośrodka, najliczniej z województw: mazowieckiego $(35,5 \%)$, łódzkiego (23,7\%), zachodniopomorskiego (5,8\%), śląskiego $(5,1 \%)$, kujawsko-pomorskiego (4,9\%), a najmniej licznie z województw, takich jak: wielko- 
polskie $(1,5 \%)$, lubuskie $(1 \%)$, małopolskie $(0,8 \%)$ i podkarpackie $(0,3 \%)$ (PORCZYK 2011). Jak już wcześniej wspomniano, wielkość ruchu turystycznego w obiektach noclegowych Spały można oszacować na ponad 60 tys. gości rocznie, co oznacza, że goście OPO generują prawie $1 / 3$ tego ruchu.

W czerwcu 2012 r. zostały przeprowadzone w Spale badania ankietowe ruchu turystycznego metodą dostępnościową. Badaniami objęto 186 osób, z których 89 (45\%) odwiedziło Spałę pierwszy raz. Struktura płci była wyrównana - 97 kobiet i 89 mężczyzn. Najliczniej reprezentowani byli goście w wieku 26-35 lat (36,5\%), 16-25 (27,4\%), mniej licznie mający 36-45 lat $(17,7 \%), 46-55(11,2 \%)$ i ponad $65(10,2 \%)$, natomiast najmniej liczną grupę stanowili respondenci w wieku 56-65 (4,8\%). Taka struktura wieku wskazuje na bardzo demograficzno-społeczną różnorodność odwiedzających i, jak wykazuje dalsza analiza, o różnych motywach przyjazdu - od czysto wypoczynkowych, turystycznych i sportowych, po biznesowe i konferencyjne. Należy dodać, że najstarsze ankietowane osoby były w wieku 81 i 82 lata. Badania nastawione były głównie na turystów indywidualnych, stąd brak reprezentacji zorganizowanych grup dzieci czy młodzieży. Wykształcenie ankietowanych osób koresponduje ze strukturą wieku - wykształcenie gimnazjalne miało zaledwie 2,1\% ankietowanych, zawodowe 2,7\%, natomiast licencjackie, średnie i wyższe odpowiednio 11,3, 38,7 i 50,5\% badanych. Podkreślić należy największy udział osób z wykształceniem wyższym. Respondenci najliczniej przybyli do Spały samochodem (73,6\%), autokarem, (10,7\%), rowerem $(9,1 \%)$ i nielicznie autobusem czy busem (4,8\%). Ponad połowa ankietowanych stwierdziła, iż przyjazd został zorganizowany indywidualnie $(51,5 \%)$, indywidualnie, ale $\mathrm{w}$ ramach spotkania (grupowy zorganizowany $38,7 \%$ ), w grupie przybyło 6,4\% badanych, inny sposób wskazało 3,2\% osób. Jako zakwaterowanie najchętniej wybierano hotel (32,2\%), następnie własny dom czy mieszkanie (19,9\% ankietowanych to wypoczywający i wycieczkowicze jednodniowi, którzy przybyli do Spały m.in. rowerem), pensjonat $(2,7 \%)$, a najmniejszym powodzeniem cieszył się nocleg $\mathrm{w}$ kwaterach prywatnych oraz w schronisku (po 1\%). Odpowiedzi odnośnie do miejsca zakwaterowania nie sprecyzowało 11,3\% ankietowanych.

Spośród form pobytu, ankietowani najczęściej deklarowali wycieczkę $(33,8 \%)$, wczasy $17,2 \%)$, pobyt $\mathrm{u}$ rodziny $(6,9 \%)$, pobyt na działce $(1 \%)$, inny (41\%, w tym pobyt służbowy zadeklarowały 44 osoby spośród 76 , a przyjazd w celach sportowych - 20 osób) (rys. 1). 


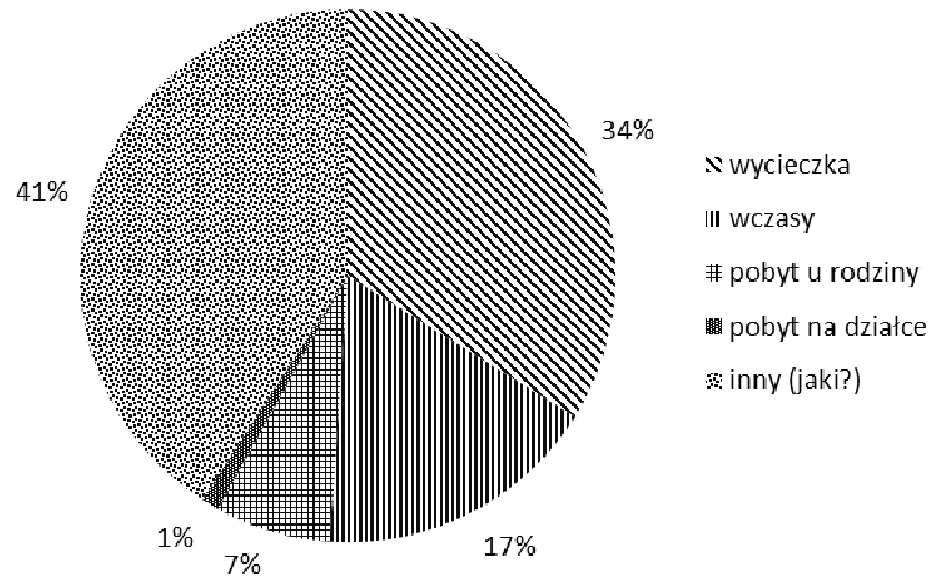

Rys. 1. Forma pobytu gości przebywających w Spale w 2012 r. Źródło: opracowanie własne na podstawie badań ankietowych $(\mathrm{N}=186)$

Charakter pobytu zdeterminowany jest głównie wiekiem respondentów, wykształceniem i miejscem pochodzenia (rys. 2 i rys. 3). W niższych przedziałach wiekowych, do 55. roku życia, zauważalny jest udział gości deklarujących "inny" charakter pobytu, co w tym przypadku oznacza udział w spotkaniach biznesowych i konferencyjnych, następnie uczestnictwo w wycieczkach i wczasach. Wśród osób w wieku powyżej 55. roku życia jako forma pobytu dominuje wycieczka, wczasy i pobyt u rodziny. Pobyt na działce deklarowali ankietowani w wieku 26-45 lat. Co do motywu przyjazdu, to osoby deklarujące "inny” charakter pobytu (głównie służbowy), uczestnicy wycieczek i wczasów legitymowali się w przeważającym stopniu wykształceniem wyższym, średnim i licencjackim. Osoby z wykształceniem gimnazjalnym i zawodowym preferowały udział $w$ wycieczce, $w$ drugiej kolejności znalazły się pobyty wczasowe, a następnie „inny”, bliżej nieokreślony charakter pobytu.

Respondenci motywują przyjazdy do Spały walorami przyrodniczymi miejscowości i okolic (69 wskazań), bliskością miejsca zamieszkania (48), możliwością aktywnego wypoczynku (39), interesującymi zabytkami (22), uczestnictwem w konferencji (22), uczestnictwem w spotkaniach biznesowych (22), namową znajomych (21), w mniejszym stopniu natomiast skierowaniem na wczasy (12), możliwością skorzystania z noclegu (5) oraz innymi (33), bliżej niesprecyzowanymi (rys. 4). 


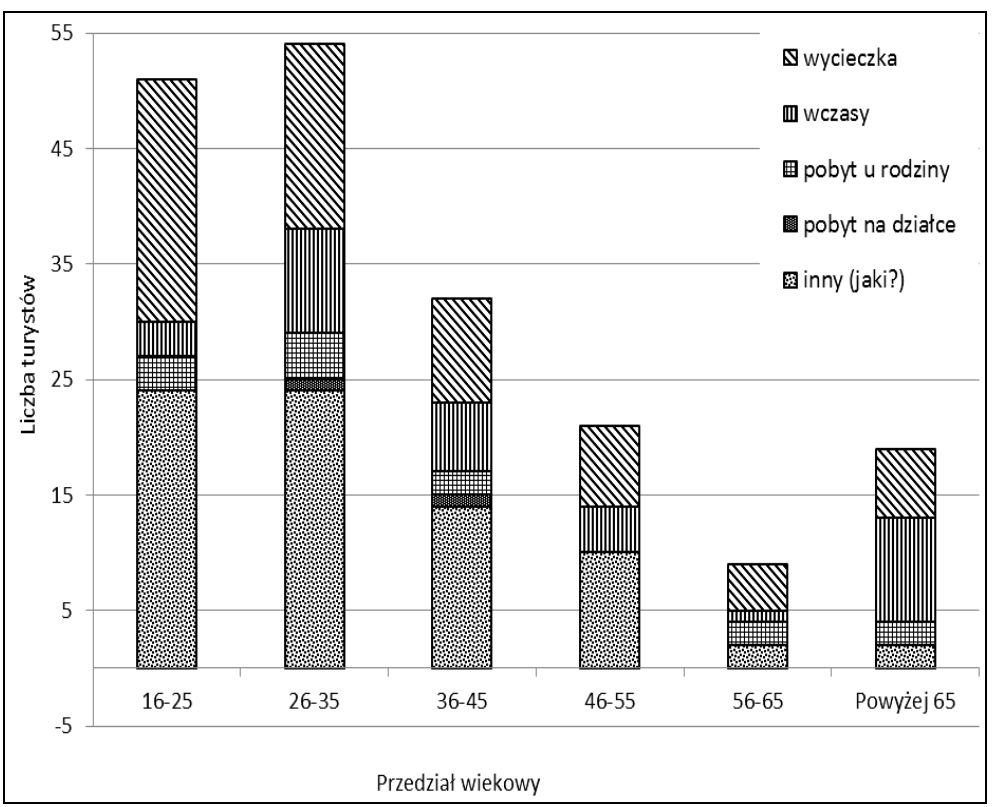

Rys. 2. Charakter pobytu w Spale a wiek respondentów

Źródło: opracowanie własne na podstawie badań ankietowych $(\mathrm{N}=186)$

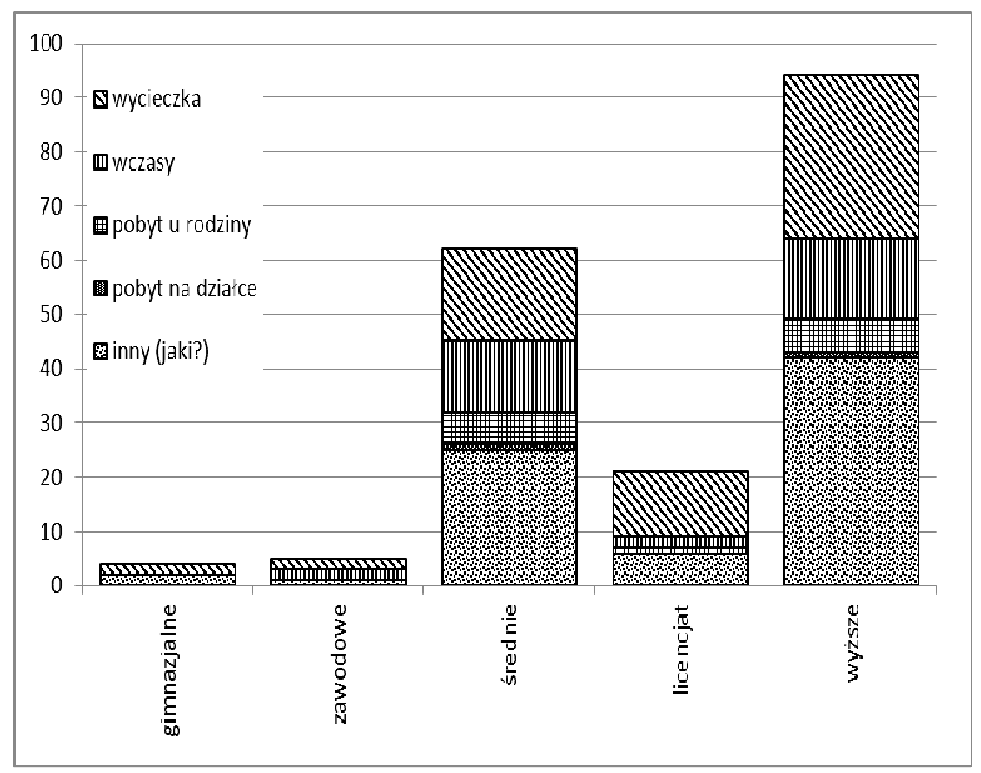

Rys. 3. Charakter pobytu w Spale a wykształcenie respondentów

Źródło: opracowanie własne na podstawie badań ankietowych $(\mathrm{N}=186)$ 


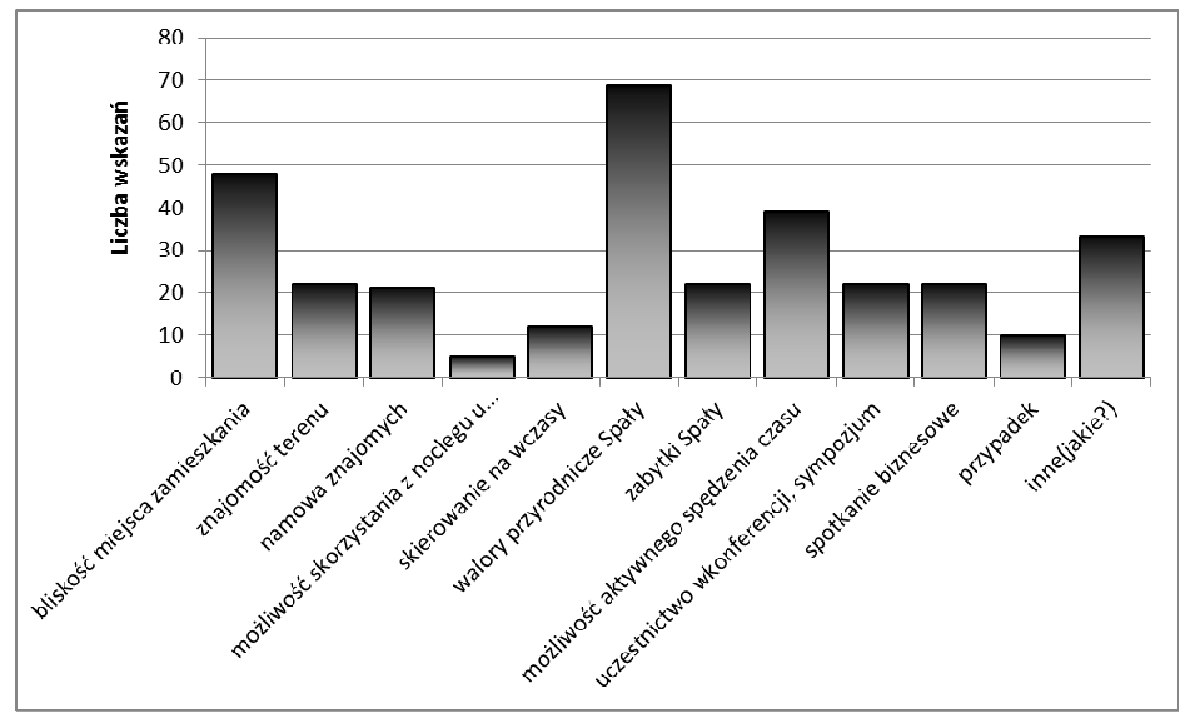

Rys. 4. Motyw przyjazdu do Spały

Źródło: opracowanie własne na podstawie badań ankietowych $(\mathrm{N}=186)$

Respondenci w wieku 16-25 lat jako główny motyw przyjazdu podają walory przyrodnicze Spały, możliwość aktywnego spędzenia czasu, bliskość miejsca zamieszkania, znajomość terenu i namowę znajomych, jak również uczestnictwo w zgrupowaniach sportowych i ćwiczeniach terenowych. Osoby w wieku 26-35 lat przybycie do Spały motywują głównie spotkaniami biznesowymi, uczestnictwem w konferencji, możliwością aktywnego spędzania czasu, walorami przyrodniczymi i bliskością miejsca zamieszkania. Dla osób w wieku 36-45 lat najważniejszymi motywami były walory przyrodnicze oraz bliskość miejsca zamieszkania. Podobnych odpowiedzi udzielili respondenci $\mathrm{w}$ wieku 46-55 lat, dodając spotkania biznesowe. Badani liczący 56-65 lat podkreślają znaczenie walorów przyrodniczych, natomiast w wieku powyżej 65 lat wymieniają skierowanie na wczasy, walory przyrodnicze i antropogeniczne oraz bliskość miejsca zamieszkania (rys. 5).

Osoby z wykształceniem wyższym podają bardzo zróżnicowane motywy przyjazdu do Spały, lecz największy udział mają spotkania biznesowe, podobnie wypowiadają się turyści z wykształceniem średnim i licencjackim.

Respondenci z wykształceniem zawodowym i gimnazjalnym wizytę w Spale motywują jej walorami, możliwością aktywnego spędzania czasu, znajomością terenu i bliskością miejsca zamieszkania (rys. 6). 


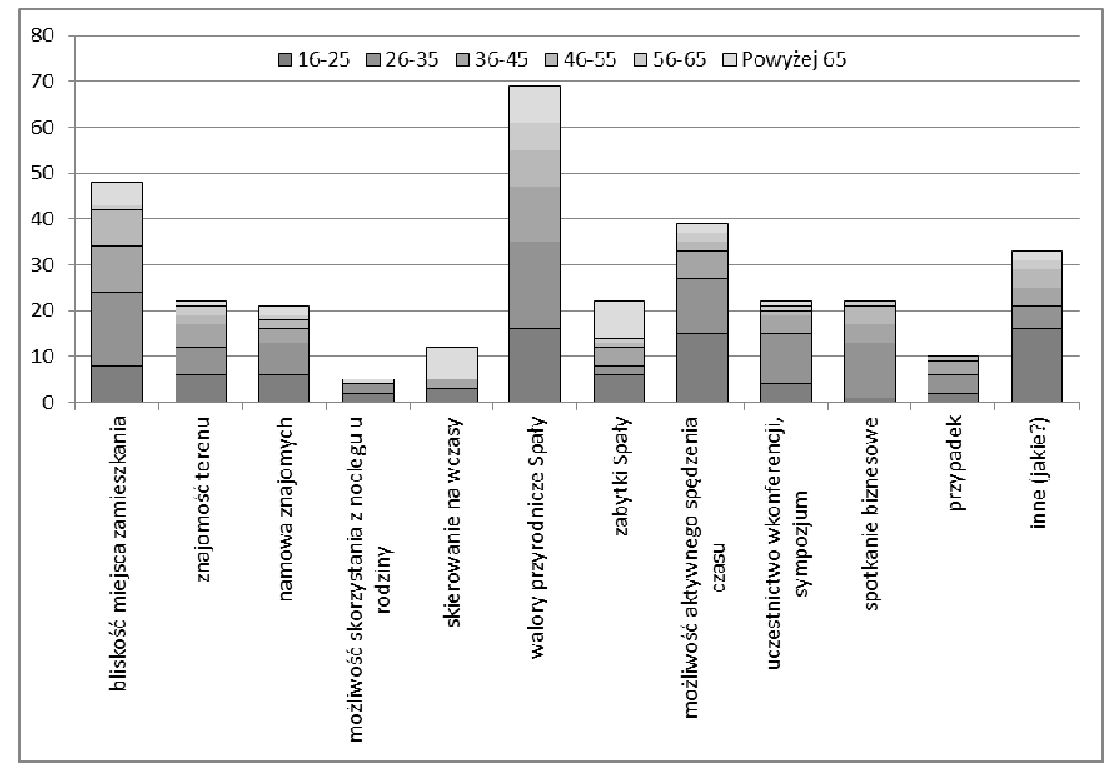

Rys. 5. Motywy przyjazdu do Spały a wiek respondentów Źródło: opracowanie własne na podstawie badań ankietowych $(\mathrm{N}=186)$

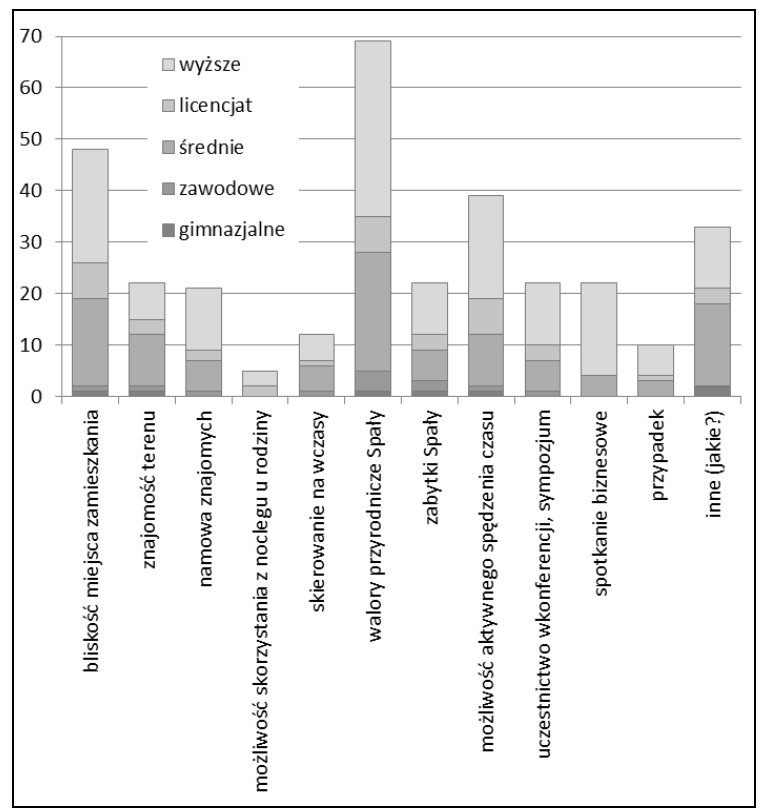

Rys. 6. Motywy przyjazdu do Spały a wykształcenie respondentów Źródło: opracowanie własne na podstawie badań ankietowych $(\mathrm{N}=186)$ 
Ponadto respondenci podkreślali udział w turystyce aktywnej podczas pobytu - najczęściej uprawiano turystykę rowerową i uczestniczono w spływach kajakowych, a ponad połowa ankietowanych (116) wskazała na spacery po Spale i spalskich lasach.

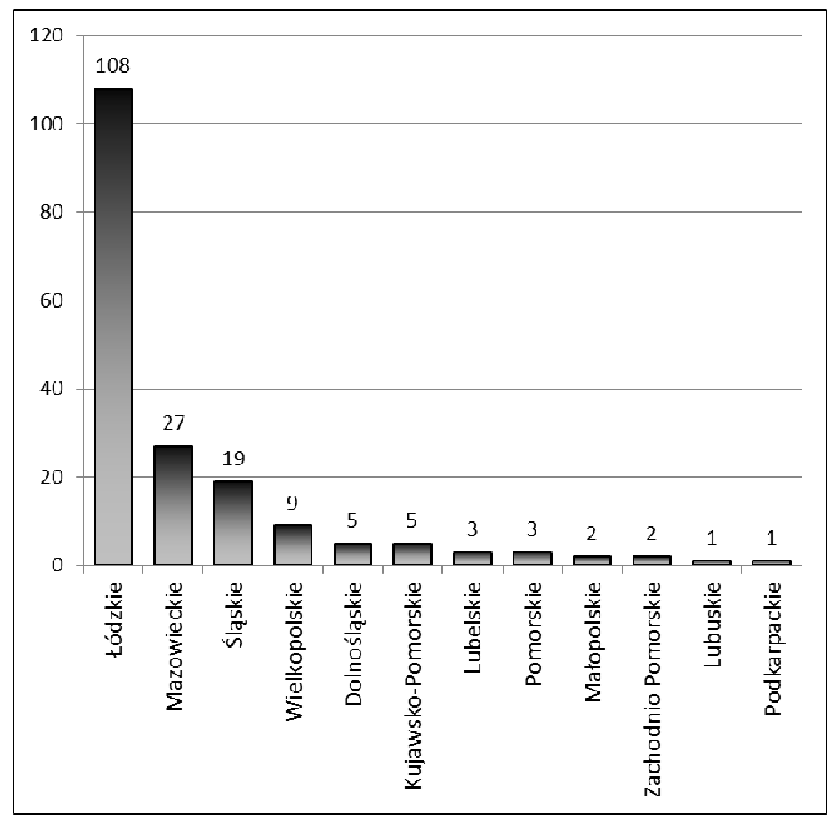

Rys. 7. Zasięg przestrzenny turystów w Spale według województw Źródło: opracowanie własne na podstawie badań ankietowych $(\mathrm{N}=186)$

Ankietowani pochodzili z 12 województw (rys. 7), zdecydowanie najwięcej osób z województw łódzkiego (Łódź, Tomaszów Mazowiecki), mazowieckiego (Warszawa) i śląskiego. Byli to zarówno wypoczywający, jak i uczestnicy konferencji oraz spotkań biznesowych. Poza tym respondenci reprezentowali województwa: wielkopolskie, dolnośląskie, kujawsko-pomorskie, lubelskie, pomorskie, małopolskie, zachodniopomorskie, lubuskie i podkarpackie.

W ogólnym zarysie miejsca pochodzenia ankietowanych turystów w Spale potwierdzają rangę krajową turystyki konferencyjnej, biznesowej oraz sportowej, lecz nade wszystko duże znaczenie wypoczynkowe Spały dla mieszkańców regionu. Turyści z województwa łódzkiego podawali 


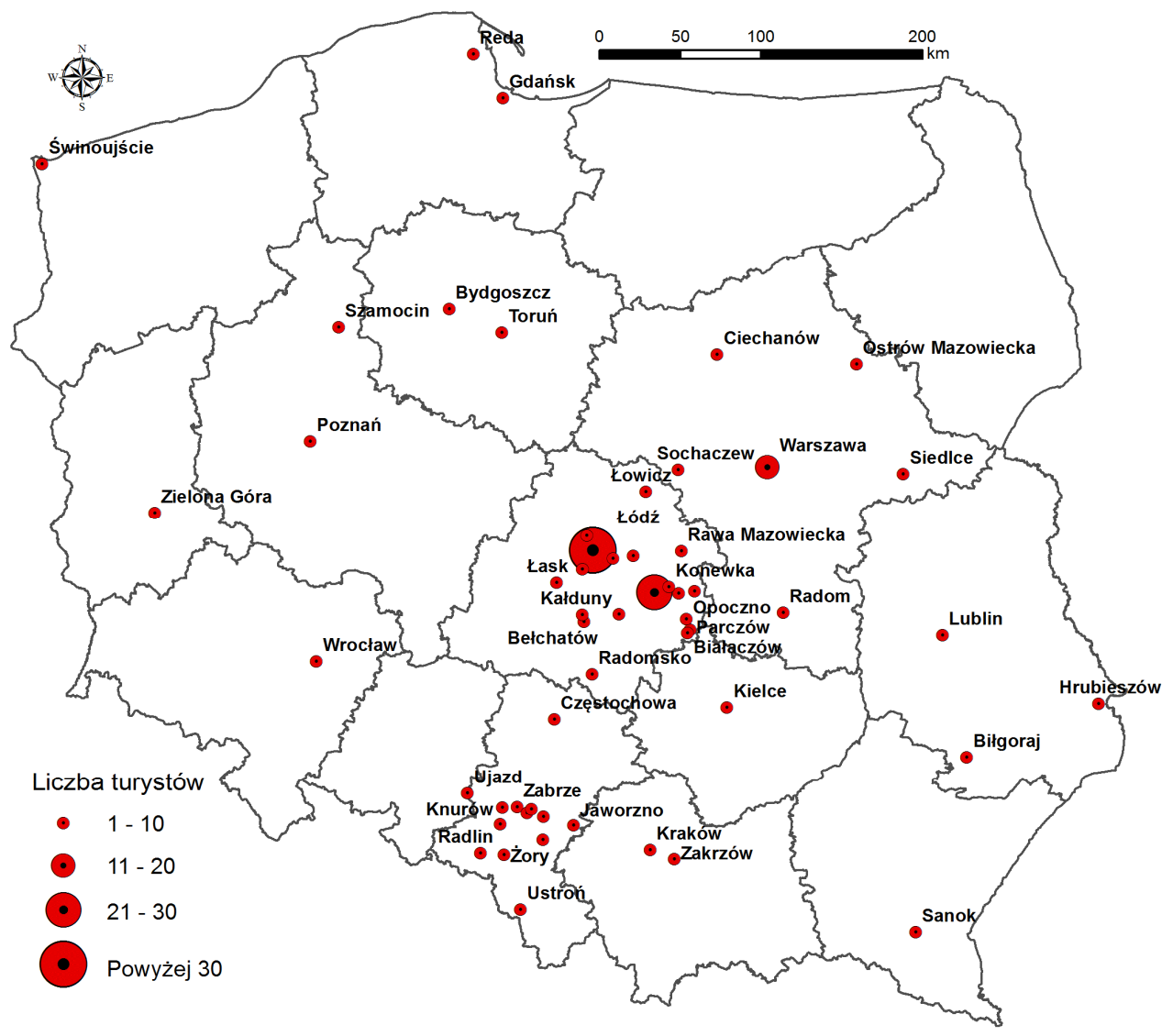

Rys. 8. Pochodzenie turystów odwiedzających Spałę według miejscowości Źródło: opracowanie własne na podstawie badań ankietowych $(\mathrm{N}=186)$

głównie jako motywy przybycia do Spały: bliskość miejsca zamieszkania (39 wskazań), walory przyrodnicze (38), możliwość uprawiania aktywnego wypoczynku (23), namowę znajomych (15), w mniejszym stopniu uczestnictwo w konferencji (8) czy w spotkaniach biznesowych (10). Wypoczywający z województwa mazowieckiego, podobnie jak mieszkańcy województwa łódzkiego, eksponowali walory przyrodnicze Spały (10 wskazań), możliwości aktywnego wypoczynku (10), uczestnictwo w konferencji (5) i w spotkaniach biznesowych (3). Respondenci z województwa śląskiego, nieco odmiennie niż poprzedni, deklarowali głównie uczestnictwo w konferencji (4) i spotkaniach biznesowych (9) oraz udział w zgrupowaniach sportowych (3). 
Mieszkańcy województwa wielkopolskiego przyjechali do Spały w celach wypoczynkowych (4) oraz sportowych (3), a województw małopolskiego, kujawsko-pomorskiego, świętokrzyskiego i pomorskiego w celu uczestniczenia w konferencji i w spotkaniach biznesowych. Goście z województw dolnośląskiego, lubuskiego czy lubelskiego natomiast to uczestnicy zgrupowań sportowych. Podczas badań odnotowano nielicznych gości z województw podkarpackiego oraz zachodniopomorskiego, którzy w Spale znaleźli się przypadkiem (tranzyt, pobyt u rodziny). Udział dużych miast (rys. 8) jako miejsca pochodzenia, szczególnie tych spoza województwa łódzkiego i mazowieckiego, sugeruje, iż byli to bardziej uczestnicy spotkań biznesowych, konferencji i zgrupowań sportowych niż tradycyjnego wypoczynku. Ponadto miejscowości województwa łódzkiego, z których przybyli ankietowani, koncentrują się w części centralnej, wschodniej i południowo-wschodniej województwa, co może oznaczać wpływ innych ośrodków wypoczynkowych na zachowania turystyczne mieszkańców regionu łódzkiego.

Badania przeprowadzone w 2012 r., podobnie jak badania z lat 20102011, wykazują dużą różnorodność ruchu turystycznego, co wskazuje na to, że Spała jako obszar recepcji turystycznej jest przygotowana na przyjęcie wczasowicza, miłośnika krajoznawstwa, uczestnika turystyki aktywnej, korporacyjnej, konferencyjnej, jak również uczestnika licznych wydarzeń, co stało się przedmiotem analizy i rozważań w dalszej części opracowania.

\section{Spała pełna wydarzeń}

Na mapie turystycznej Polski Spała zaistniała nie tylko dzięki walorom przyrodniczym, lecz także antropogenicznym, z których najistotniejszą rolę odgrywają imprezy kulturalne. Spała bywa gospodarzem zarówno wydarzeń okazjonalnych (których znaczenie jest zwykle lokalne, jak np. Dzień Dziecka), jak i cyklicznych, goszczących przyjezdnych z całej Polski, a niejednokrotnie i z zagranicy. Wydarzenia te związane są z jednej strony z zagospodarowaniem Spały (do tych zaliczyć należy imprezy sportowe, których gospodarzem jest OPO), z drugiej zaś wykorzystują potencjał przyrodniczy $\mathrm{w}$ połączeniu $\mathrm{z}$ tradycjami sięgającymi międzywojnia, kiedy prezydent Ignacy Mościcki zapoczątkował zwyczaj dożynek prezydenckich oraz obchodów dnia św. Huberta we wsi stanowiącej letnią siedzibę prezydentów Rzeczypospolitej. 
Dożynki prezydenckie po raz pierwszy miały miejsce w 1927 r. Świętowano je każdego roku aż do wybuchu II wojny światowej. Do tradycji tej powrócił w roku 2000, z inicjatywy premiera Romana Jagielińskiego, prezydent Aleksander Kwaśniewski. Wówczas dożynki spalskie miały znaczenie ogólnopolskie. W pierwszym okresie prezydentury Lecha Kaczyńskiego, w latach 2006-2008 miały charakter regionalny, a od 2009 r. ponownie krajowy. Tradycyjnymi punktami uroczystości są msza święta oraz ceremoniał dożynkowy, który odbywa się w OPO (http://www.spala.pl/imprezy/ dozynki/).

Spała w końcu XIX w. zasłynęła z doskonałych terenów łownych, a do jej popularyzacji przyczynił się car Aleksander III (PODOLSKA, JAGIEŁŁO 2012). Wieś i dziś stanowi idealne miejsce do obchodów święta patrona myśliwych, leśników i jeźdźców - św. Huberta z Liège. Święty Hubert wspominany jest w Kościele katolickim 3 listopada, stąd obchody hubertusa mają miejsce zwykle w końcu października lub w początkach listopada. W Spale zapoczątkował je w 1930 r. prezydent Ignacy Mościcki, a tradycję wskrzeszono w 1999 r. Hubertus spalski jest największą w Polsce plenerową imprezą myśliwską i jeździecką do której sukcesu przyczynia się kompleksowa organizacja, w którą zaangażowane są instytucje myśliwskie (Polski Związek Łowiecki), turystyczne (Lokalna Organizacja Turystyczna w Spale), Lasy Państwowe (http://www.lodz.lasy.gov.pl/web/rdlp_lodz/217) i stowarzyszenie STER. Wydarzeniu towarzyszy msza święta, polowania, pokot, pokazy jeźdźców, sokolników, łuczników, myśliwych i hodowców psów oraz Jarmark Hubertowski (http://www.hubertusspalski.pl).

Przełom XX i XXI w. w Spale to nie tylko odrodzenie się starych tradycji, lecz także kreowanie nowych, do których należy Spalski Jarmark Antyków i Rękodzieła Ludowego.

\section{Spalski Jarmark Antyków i Rękodzieła Ludowego w świetle badań ankietowych - czerwiec 2012 r.}

W dniach 9 i 10 czerwca 2012 r. studenci I roku uzupełniających stacjonarnych studiów magisterskich kierunku "turystyka i rekreacja” realizowali w ramach przedmiotu "Geografia turyzmu i hotelarstwa” badania terenowe, których celem było poznanie specyfiki Spalskiego Jarmarku Antyków i Rę- 
kodzieła Ludowego. Zamierzeniem było przeprowadzenie ankiet ze wszystkimi wystawcami, wybranymi uczestnikami oraz monitoring aut pozostawionych na spalskich parkingach i ulicach. Wyniki badań przyczyniły się do lepszego poznania imprezy, która w 2005 r. wpisała się w kalendarz wydarzeń kulturalnych Spały i stała się jednym z jej najlepszych produktów, o czym świadczy certyfikat Polskiej Organizacji Turystycznej z 2007 r. przyznawany za Najlepszy Produkt Turystyczny Roku. O wyborze terminu badań zdecydowało bezprecedensowe wydarzenie w historii jarmarku - wydłużenie czasu trwania z jednego do dwóch dni (do 2012 r. impreza miała miejsce od kwietnia do października, zwykle w pierwszej połowie miesiąca, wyłącznie w niedziele; zaś w 2012 r. w miesiącach letnich - czerwcu, lipcu

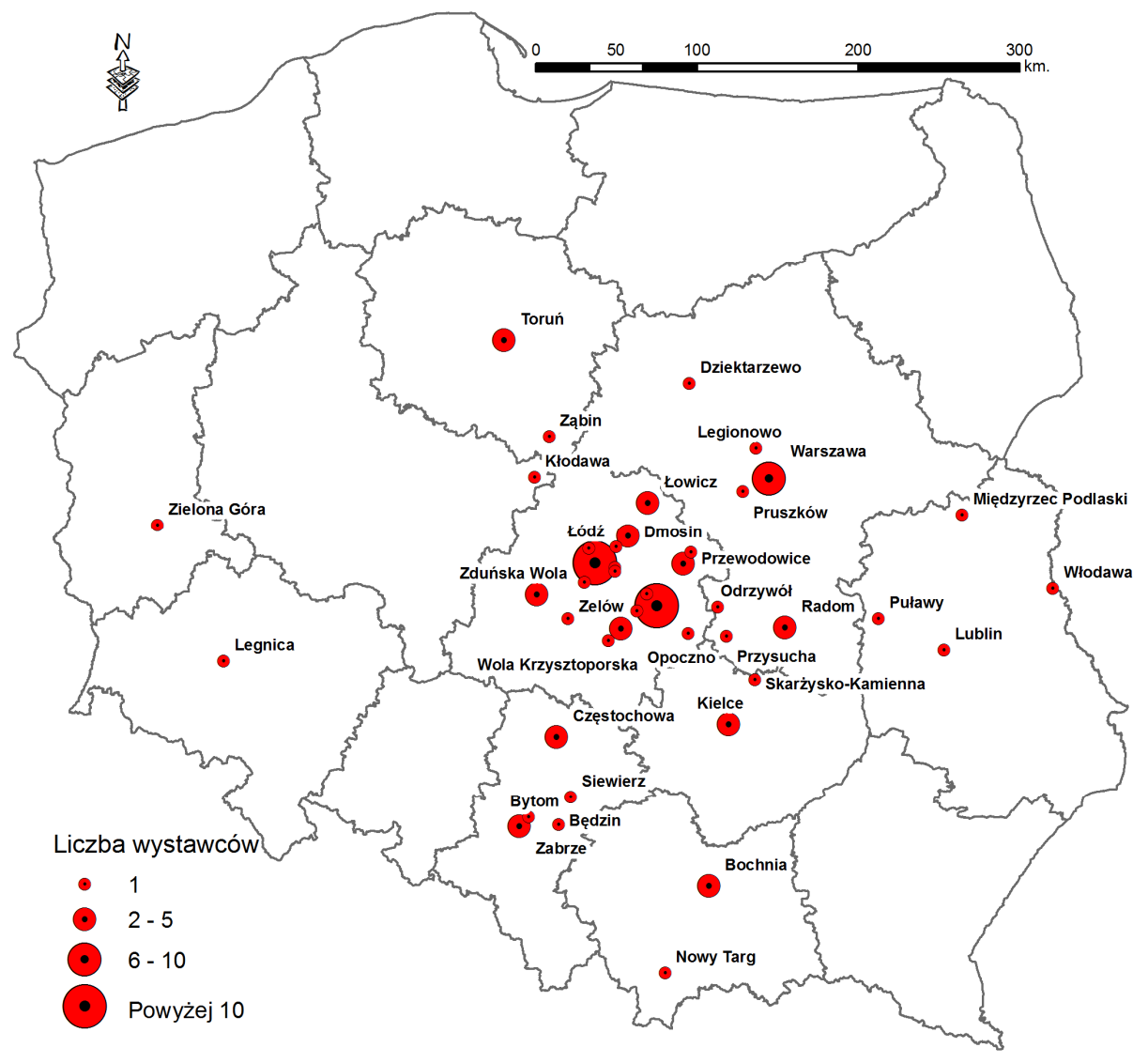

Rys. 9. Pochodzenie wystawców według miejscowości Źródło: opracowanie własne na podstawie badań ankietowych $(\mathrm{N}=112)$ 
i sierpniu - jarmark odbywał się w soboty i niedziele). Szczegółowe informacje dotyczące charakteru tej imprezy oraz jej organizacji zawiera Regulamin Spalskiego Jarmarku Antyków i Rękodzieła Ludowego dostępny na oficjalnej stronie internetowej http://www.jarmark spalski.pl/.

W jarmarku odbywającym się w dniach 9-10 czerwca 2012 r. uczestnictwo zadeklarowało 172 wystawców, z czego udział w ankiecie wzięło 112 osób - 45 kobiet i 67 mężczyzn. Przeprowadzenie wywiadów ankietowych ze wszystkimi okazało się niemożliwe - część wystawiających nie wyraziła na nie zgody, rozmowy z pozostałymi przeciągały się, przerywane przez kupujących.

Średnia wieku badanych wynosiła 46 lat, z czego najmłodszy miał 18, a najstarszy 69 lat. Struktura wykształcenia ankietowanych jest zróżnicowana - dominowały osoby z wykształceniem średnim (44\%), w dalszej kolejności znalazły się z wyższym (27\%) oraz zawodowym (22\%). Miejsce zamieszkania wystawców oddalone jest średnio o $93 \mathrm{~km}$ od Spały - większość pochodziła $\mathrm{z}$ województwa łódzkiego oraz mazowieckiego, nieliczni przybyli z miejscowości położonych w województwach: lubuskim, dolnośląskim, śląskim, małopolskim, świętokrzyskim, lubelskim i kujawsko-pomorskim (rys. 9).

Zaledwie 26\% wystawców zdecydowało się na nocleg w Spale, przy czym w większości, ze względów finansowych oraz w trosce o swój towar, nie korzystano ze spalskiej bazy noclegowej przystosowując do spania własne auta.

Regulamin Spalskiego Jarmarku Antyków i Rękodzieła Ludowego określa go jako imprezę cykliczną i taką też jest dla wystawców. Aż 55\% ankietowanych pojawiło się na nim ponad pięć razy, przy czym część z nich przyjeżdża do Spały od końca lat 90. XX w., kiedy to handel starociami w Spale miał charakter nieformalny. Zaledwie $14 \%$ ankietowanych pojawiło się na jarmarku po raz pierwszy (rys. 10).

Zgodnie z regulaminem, wystawcy nie powinni sprzedawać alkoholu, wyrobów tytoniowych oraz innych używek bez zgody organizatora, nie mogą handlować lekami i parafarmaceutykami, materiałami palnymi, częściami samochodowymi, odzieżą i zabawkami (z wyłączeniem rękodzieła), artykułami fonograficznymi oraz wyrobami gastronomicznymi. Jak wskazuje nazwa imprezy, powinni wystawiać antyki, rękodzieło ludowe - i te produkty dominowały na zinwentaryzowanych stanowiskach (antyki $-36 \%$, rękodzieło - 17\%). Wśród produktów przeznaczonych na sprzedaż pojawiła 
się również zdrowa żywność (11\%), ceramika i porcelana (11\%), biżuteria w tym chińska (20\%), a także asortyment wykraczający poza postanowienia regulaminu, jak np. pościel, części motorowe i rowerowe, zabawki (w tym maskotki), słodycze, okulary przeciwsłoneczne, kosmetyki i perfumy (także popularnych firm koncentrujących dystrybucję na bezpośredniej sprzedaży). Te odstępstwa od regulaminu wynikają z faktu, iż wystawcy są kwalifikowani do udziału $\mathrm{w}$ jarmarku na podstawie informacji, które zamieszczają $\mathrm{w}$ formularzu zgłoszeniowym, tym samym przed imprezą organizatorzy nie są w stanie zweryfikować asortymentu. Jednakże kolejne zgłoszenia wystawców, którzy prezentowali towar niezgodny z regulaminem, nie są rozpatrywane pozytywnie.

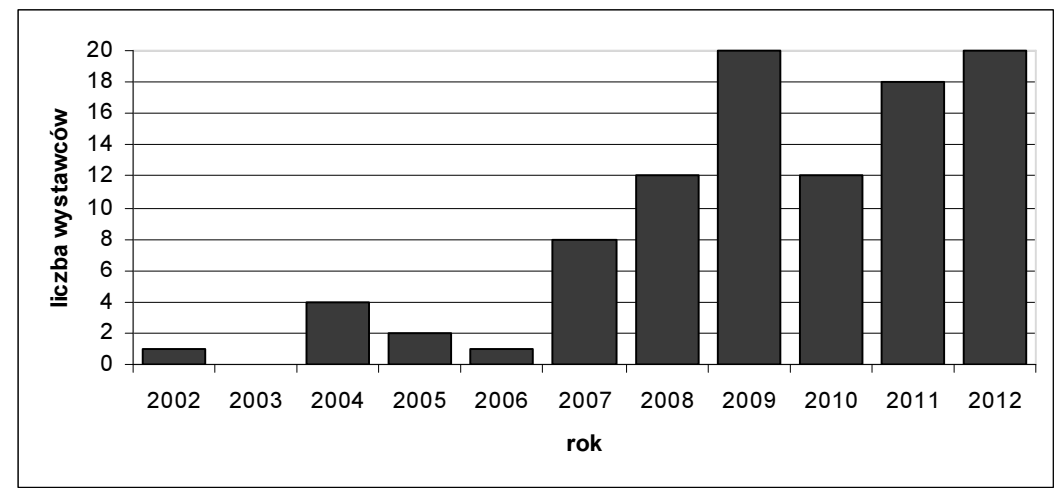

Rys. 10. Zadeklarowana data pierwszego przyjazdu wystawców na jarmark w Spale Źródło: opracowanie własne na podstawie badań ankietowych $(\mathrm{N}=112)$

Ważne opinie dotyczące imprezy pojawiły się również $\mathrm{w}$ wypowiedziach odwiedzających ją. Liczba gości jarmarku jest trudna do oszacowania ze względu na fakt, że uczestnictwo w nim jest bezpłatne. Szacunki prowadzić można na podstawie liczby aut pozostawionych na spalskich ulicach i parkingach. W ciągu dwóch dni zarejestrowano 1983 pojazdy, należy jednak wziąć pod uwagę, że część z nich mogła należeć do samych wystawców. Nieznana jest też dokładna liczba osób przybyłych do Spały innymi środkami transportu. Na podstawie monitoringu aut stwierdzić jednakże można, że na jarmark przybywają goście z całej Polski (w odniesieniu do województw), przy czym dominują przyjezdni z województwa łódzkiego oraz mazowieckiego (rys. 11). 
A
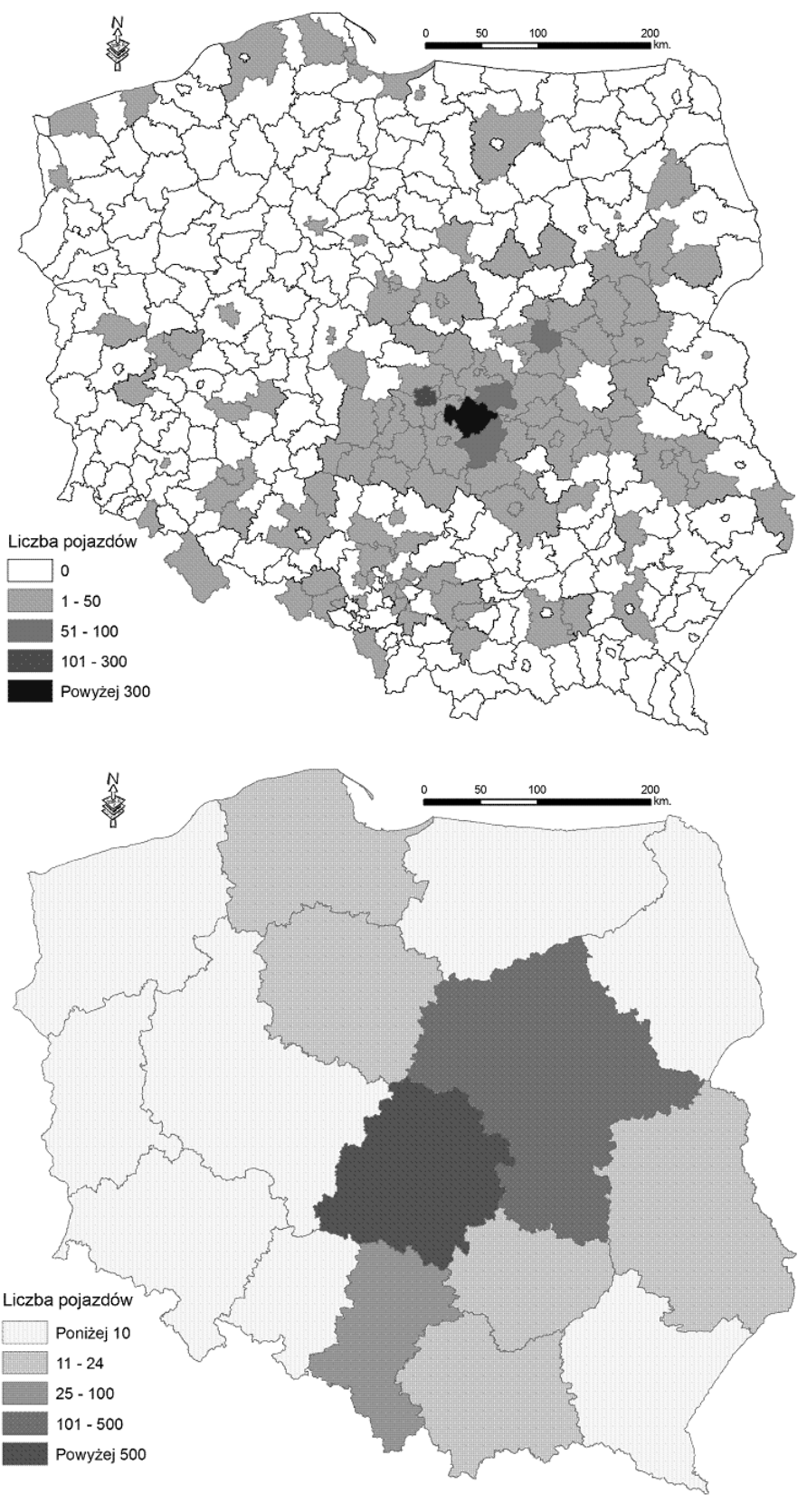

$\mathrm{B}$

Rys. 11. Liczba aut spisanych na spalskich ulicach $w$ dniach 9-10.06.2012 r. według rejestracji w podziale na powiaty (A) i województwa (B) Źródło: opracowanie własne na podstawie badań ankietowych 
Spośród odwiedzających jarmark w ankiecie udział wzięło 174 uczestników - 95 kobiet i 79 mężczyzn, których średnia wieku wyniosła 40 lat (rozpiętość wiekowa od 17 do 83 lat). Uczestnicy przybyli głównie z miejscowości położonych w województwie łódzkim oraz mazowieckim (rys. 12).

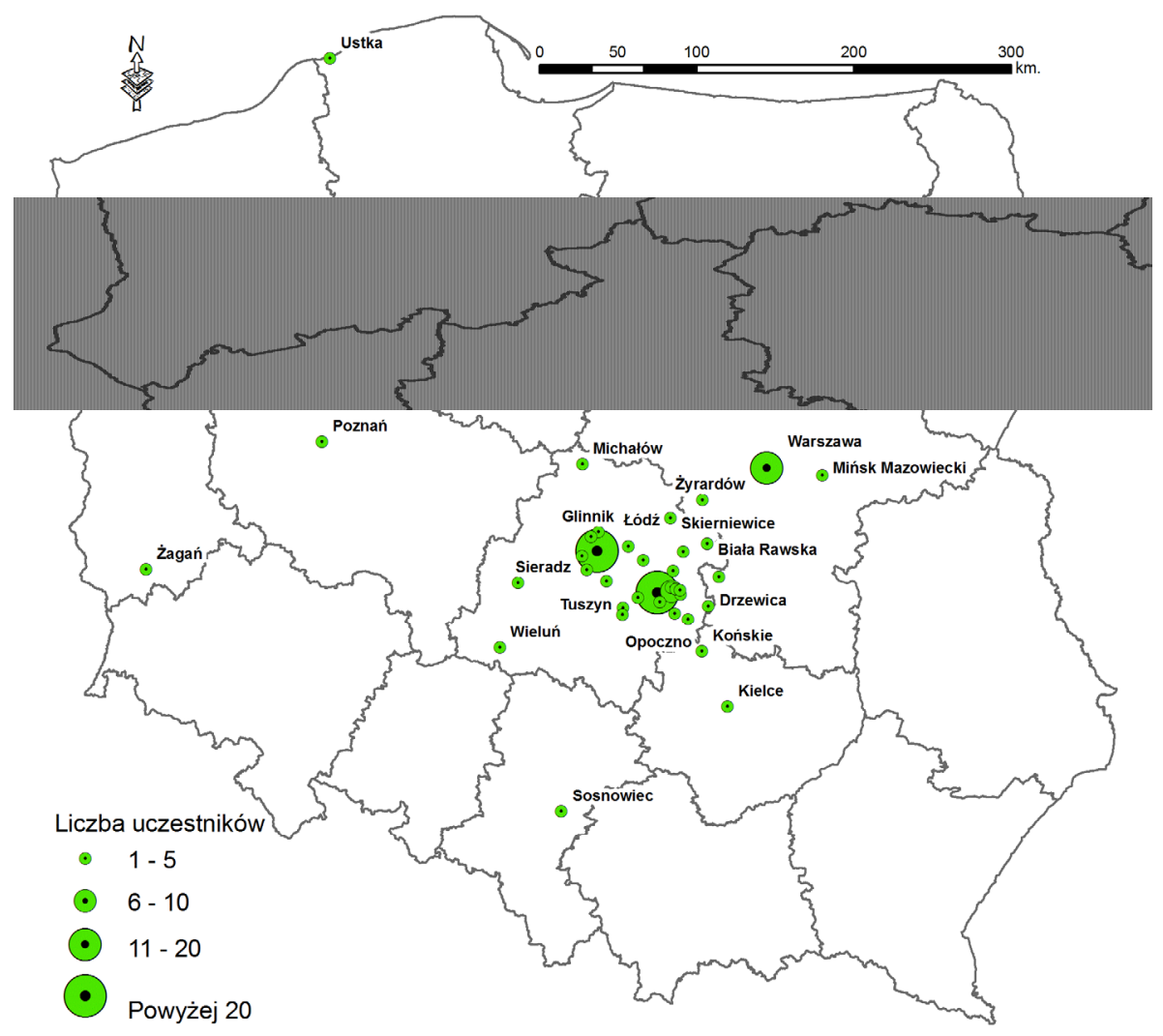

Rys. 12. Pochodzenie ankietowanych uczestników jarmarku w Spale według miejscowości Źródło: opracowanie własne na podstawie badań ankietowych $(\mathrm{N}=174)$

Większość rozmówców miała wykształcenie wyższe magisterskie (45\%) bądź licencjackie (10\%), 25\% - średnie, zaś 17\% - zawodowe. Podobnie jak wystawcy, także uczestnicy w większości (74\%) nie zdecydowali się na nocleg w Spale, gdyż, jak twierdziło 76\% spośród nich, przyjechali do Spały na kilka godzin. Spośród pozostałych $26 \%$ ankietowanych, którzy nocowali w Spale, byli goście spalskich obiektów noclegowych (w tym: bazy UŁ, 
hotelu „Mościcki”, Carskiej Oranżerii, FWP, Dworu Carskiego, Ostoi) oraz mieszkańcy Spały - wszyscy oni odwiedzili jarmark podczas pobytu we wsi, niejednokrotnie dowiadując się o nim przypadkiem, podczas spaceru. $\mathrm{Na}$ uwagę zasługuje fakt, że 59\% ankietowanych zadeklarowało, iż przyjechało na jarmark po raz kolejny. Większość ankietowanych, aż 92\%, przybyło $\mathrm{w}$ ramach wyjazdu indywidualnego. $\mathrm{Z}$ przeprowadzonych badań wynika, że jarmark jest czynnikiem stymulującym turystykę rodzinną - aż 65\% ankietowanych przyznało, że pojawiło się na nim z członkami rodziny. Tym samym nie dziwi fakt, że aż 75\% jako środek transportu wybrało samochód, ale $\mathrm{w}$ ankiecie wzięły też udział osoby, które dotarły do Spały rowerem $(8 \%)$, autobusem ( $6 \%$ ) oraz pieszo (5\%). Jako główne motywy uczestnictwa w jarmarku podawano bliskość miejsca zamieszkania (33\%), wskazywano na renomę jarmarku (17\%), namowę znajomych (14\%) oraz inne (w tym zakupy, zainteresowania wystawianym towarem, ćwiczenia terenowe $\mathrm{w}$ ramach studiów, ciekawość, przyzwyczajenie, rekreacja, przypadkowe dotarcie na jarmark podczas spaceru, wypoczynku czy przejazdu przez Spałę).

Zarówno wystawcy, jak i uczestnicy poproszeni zostali o ocenę jarmarku w skali od 1 (negatywna) do 5 (bardzo dobra). I wystawcy (91\%), i uczestnicy (90\%) uznali go za wydarzenie atrakcyjne, jednakże poszczególne jego komponenty oceniano różnie. Wysokie noty przyznano za atmosferę panującą podczas tej imprezy (uczestnicy $-4,2$, wystawcy $-4,5$ ) oraz organizację (uczestnicy - 3,8, wystawcy - 4,4). Najgorzej oceniono promocję jarmarku (uczestnicy - 2,9, wystawcy - 3,7). Głównym źródłem informacji o tym wydarzeniu okazali się znajomi (dla 45\% uczestników i 63\% wystawców) oraz Internet (20\% wystawców i 30\% uczestników). Uczestnicy, częściej niż wystawcy, wskazywali też na informacje w prasie $(17 \%)$, radiu $(2 \%)$ oraz inne (przypadek, ulotki i informatory turystyczne, informacja turystyczna, obiad w okolicy czy przejazd przez Spałę). Dzielono się także uwagami dotyczącymi organizacji, które dotyczyły:

1) informacji - wystawcy postulowali zwiększenie działań promocyjnych, rozbudowę strony internetowej Spalskiego Jarmarku Antyków i Rękodzieła Ludowego o szczegółowe opisy wystawców;

2) infrastruktury - zarówno wystawcom, jak i uczestnikom doskwierała nawierzchnia (pył unoszący się podczas suchych dni prowadzi do zakurzenia towarów, $\mathrm{w}$ dni deszczowe ścieżki między straganami są trudne do pokonania $\mathrm{w}$ nieodpowiednim obuwiu), brak miejsca za- 
baw dla dzieci, niedostateczna liczba, wysoka cena i godziny otwarcia toalet, brak strzeżonego parkingu dla wystawców;

3) asortymentu - i wystawcy, i uczestnicy chcieliby widzieć na stoiskach jarmarku, nomen omen, antyki i rękodzieło, przy czym uczestnicy produkty te w niższych cenach;

4) imprez towarzyszących - ich brak doskwierał przede wszystkim w sobotę.

Podsumowując, Spalski Jarmark Antyków i Rękodzieła Ludowego jest atrakcyjnym wydarzeniem dla jednodniowych odwiedzających, dla których staje się głównym motywem przyjazdu do Spały w weekendy, w których się odbywa. Negatywne oceny dotyczące tej imprezy wynikają z niskiej oceny infrastruktury (nawierzchnia, toalety, brak strzeżonego parkingu dla wystawców) oraz nieprzestrzegania Regulaminu przez handlujących, a także niedostatecznej promocji. Dotyczy to także informacji o noclegach w Spale. W związku z wydłużeniem czasu imprezy do dwóch dni pojawiła się oferta przygotowana przez FWP, jednakże promowana była głównie na internetowej stronie startowej jarmarku, link do pliku PDF z ofertą był niewidoczny na poszczególnych zakładkach, dlatego też konieczna jest zmiana layoutu oficjalnej strony internetowej imprezy.

\section{Zakończenie}

Przeprowadzona analiza wskazała na specyfikę gości spalskiego jarmarku w odniesieniu do pozostałych odwiedzających Spałę. Zarówno badania jego uczestników, jak i innych turystów odbywały się w czerwcu, można by więc spodziewać się, że wyniki ankiet w danym sezonie powinny być zbieżne. Tymczasem jednak grupa gości przybywających na jarmark wykazuje odrębność społeczno-geograficzną; w większości są to osoby z wykształceniem wyższym. O ile w Spale wypoczywają goście z całej Polski, o tyle uczestnicy jarmarku pochodzą z okolicznych miejscowości położonych w województwie łódzkim bądź mazowieckim. Zarówno turyści, jak i odwiedzający jarmark jako środek transportu wybierają samochód (w obu przypadkach ponad 70\% ankietowanych), podobny jest również udział przybyłych rowerem (8-9\%). Ankietowani turyści korzystali z noclegu w Spale, zaś 3/4 osób przybyłych na jarmark zaplanowało wizytę we wsi na zaledwie kilka godzin. 
Odmienne są również motywy przyjazdu do Spały dla turystów oraz uczestników jarmarku. Turyści cenią przede wszystkim spalską przyrodę, zaś przybyli na jarmark deklarują bliskość miejsca zamieszkania jako główny czynnik decydujący o wizycie w tej wsi. W obu przypadkach jednym z ważniejszych motywów była również namowa znajomych.

Jarmarki towarzyszą prawie każdej większej imprezie plenerowej odbywającej się na terenie Spały. Jednak Spalski Jarmark Antyków i Rękodzieła Ludowego jest wydarzeniem "samym w sobie”, wykreowanym jako produkt turystyczny miejscowości. I choć już nie jest imprezą zupełnie nowa, niewątpliwie przyciąga do Spały kolejnych bywalców, kreując jednocześnie nowatorską dla Spały formę turystyki i odmienny segment turystów. Jarmark wnosi powiew świeżości w strukturę ruchu turystycznego Spały, którego większość stanowią uczestnicy zgrupowań i wydarzeń sportowych oraz konferencji, zjazdów i sympozjów. Jarmark jest wyjątkową imprezą integracyjną dla rodzin, podczas której każdy znajdzie dla siebie oryginalny „smaczek", nie tylko na stoiskach z kulinariami.

\section{BIBLIOGRAFIA}

LATOSIŃSKA J., ŻEK M., 2011, Funkcja turystyczna Spały, [w:] Turystyka polska w latach 1989-2009, ser. „Warsztaty z Geografii Turyzmu”, Wyd. Uniwersytetu Łódzkiego, Łódź, s. 93-114.

PodOLSKA J., JAGIEŁŁo M., 2012, Spacerownik. Rosyjskimi śladami po województwie łódzkim, Agora SA, Łódź.

PORCZYK A., 2011, Funkcja sportowo-turystyczna Centralnego Ośrodka Sportu w Polsce, maszynopis pracy magisterskiej wykonanej w Instytucie Geografii Miast i Turyzmu, Uniwersytetu Łódzkiego.

PRZECŁAWSKI K., 1996, Człowiek a turystyka. Zarys socjologii turystyki, ALBIS, Kraków.

Wielka encyklopedia PWN, 2002, t. 12, PWN, Warszawa.

http://www.jarmarkspalski.pl/.

http://www.hubertusspalski.pl.

http://www.lodz.lasy.gov.pl/web/rdlp_lodz/217.

http://www.spala.pl/imprezy/dozynki/. 